\title{
Synthesis, characterization, and pharmacological evaluation of some metal complexes of quercetin as P-gp inhibitors
}

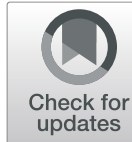

\author{
Kirankumar Shastrala', Sirisha Kalam ${ }^{1 *}$ D, Kumaraswamy Damerakonda', Sharvana Bhava Bandaru Sheshagiri ${ }^{1}$, \\ Hitesh Kumar ${ }^{1}$, Ramu Guda², Mamatha Kasula ${ }^{2 *}$ and Satish Kumar Bedada ${ }^{3}$
}

\begin{abstract}
Background: Six different metal complexes of quercetin ( $\mathrm{Cu}, \mathrm{Zn}, \mathrm{Co}, \mathrm{Vd}, \mathrm{Mo}, \mathrm{Ni})$ were synthesized, purified, and characterized by their physical and spectral (UV, IR) data. They were evaluated for their P-gp (permeability glycoprotein) inhibitory activity by in vitro everted sac method in rats. The apparent permeability of atorvastatin ( $P$ gp substrate) from everted sac of the rat intestine was determined in control, standard (verapamil), and groups treated with quercetin-metal complexes. The drug contents were analyzed by validated RP-HPLC method using a mixture of acetonitrile and water (60:40 v/v) adjusted to $\mathrm{pH} 2.8$ with phosphate buffer as mobile phase.

Results: In vitro studies revealed that the apparent permeability of atorvastatin (P-gp substrate) across the small intestine is much affected by the treatment with $\mathrm{Cu} / \mathrm{Co} / \mathrm{Ni}$ complexes of quercetin. The mean $\pm \mathrm{SD}$ and apparent permeability of atorvastatin decreased after pre-treatment with these metal complexes.
\end{abstract}

Conclusions: The quercetin $\mathrm{Cu} / \mathrm{Co} / \mathrm{Ni}$ complexes could inhibit P-gp and increase the atorvastatin absorption. Hence, they could be considered P-gp inhibitors.

Keywords: Quercetin, Metal complexes, Atorvastatin, P-gp, Inhibitors, P-glycoprotein

\section{Background}

Cancer is a dreadful disease, killing a large number of the population worldwide. More than 100 different types of cancer are reported to affect humans [1,2]. Chemotherapy is widely used for cancer treatment but it is hindered mostly due to the resistance of tumor cells to anticancer drugs $[3,4]$. Several mechanisms underlying drug resistance were identified. Increased efflux of drugs by cancerous cells, due to over expression of membrane transporter proteins (efflux pumps) is one of the major mechanisms documented. P-glycoprotein (P-gp) is the first discovered multidrug transporter that pumps drugs out of tumor

\footnotetext{
* Correspondence: ragisirisha@gmail.com; mamatakasula@gmail.com

'Departments of Pharmaceutical Chemistry and Pharmacology, Vaagdevi

College of Pharmacy, Ramnagar, Hanamkonda, Warangal, Telangana 506001, India

${ }^{2}$ Department of Chemistry, Kakatiya University, Vidyaranyapuri, Warangal,

Telangana 506009, India

Full list of author information is available at the end of the article
}

cells, resulting in decreased intracellular drug concentrations and thus reducing the efficacy of drugs [5]. It is present in several normal tissues like intestinal lining epithelium, endothelial cells, and bone marrow.

Quercetin $(\mathrm{Q})$ is a major naturally occurring flavonoid, belonging to the class of flavonols. It is ubiquitously found in a wide variety of plant products like coffee, tea, dyes, vegetables, and fruits [6]. The beneficial effects of quercetin are mostly due to its free radical scavenging or antioxidant property and its ability to chelate metal ions $\left(\mathrm{Fe}^{2+}\right.$ and $\left.\mathrm{Fe}^{3+}, \mathrm{Cu}^{2+}, \mathrm{Ni}^{2+}\right)[7-12]$. Quercetin and some of its metal complexes displayed various biological actions such as antimicrobial, antiulcer, antiallergic, antiAlzheimer's, and anticancer [13-18]. It was reported that quercetin could competitively inhibit the members of MDR family, P-gp, MRP1, and BCRP [19-23]. But, hitherto, there are no reports on the P-gp inhibitory activity of quercetin-metal complexes. In this regard, the present 
work was aimed to synthesize, characterize, and pharmacologically evaluate the metal $(\mathrm{M})$ complexes of quercetin $(\mathrm{M}=\mathrm{Cu}, \mathrm{Zn}, \mathrm{Mo}, \mathrm{VO}, \mathrm{Ni}, \mathrm{Co})$ for their P-gp (Pglycoprotein) inhibition activity by in vitro rat everted sac method in Wistar albino rats [24, 25], as this model despite a few limitations is an economic, simple, and highly efficient tool in investigating the effect of P-gp inhibitors across the small intestine of rats and serves to predict the drug absorption in humans.

\section{Methods}

\section{Drugs and chemicals}

The drug atorvastatin was purchased from Stallion Laboratories Pvt. Ltd., Ahmedabad; verapamil was purchased from Ranbaxy Laboratories Ltd., Hyderabad; and quercetin was obtained from Sigma Aldrich Chemicals, Bangalore. HPLC-grade methanol and acetonitrile and $\mathrm{BDH}$-grade of the chemicals copper chloride dihydrate, zinc chloride hexahydrate, ammonium molybdate, vanadyl sulphate monohydrate, nickel chloride hexahydrate, cobaltous chloride hexahydrate, and hydrochloric acid were purchased from Qualigens Fine Chemicals, Mumbai. Dimethyl sulfoxide, sodium hydroxide, and hexane were obtained from Finar Chemicals, Mumbai. Dulbecco's phosphate buffer $\mathrm{pH}$ of 7.4 was purchased from Hi Media Ltd., Mumbai, and HPLC-grade water was procured from S.R. Enterprises, Hanamkonda.

\section{Instruments}

UV-visible double-beam spectrophotometer (Shimadzu UV-1800, 240V, 2010), FT-IR spectrophotometer (Bruker ALPHA, 2011), HPLC (Cyberlab, SPD-10A UV-Vis detector, LC 10AD pump, 2011), refrigerator (LG 360L, 2008), electronic weight balance (Shimadzu AUY 220, 2011), sonicator (Electric supply 1.5L50, 2010), electromagnetic stirrer (Remi G3M5-3600, 2008), and vacuum desiccators were used.

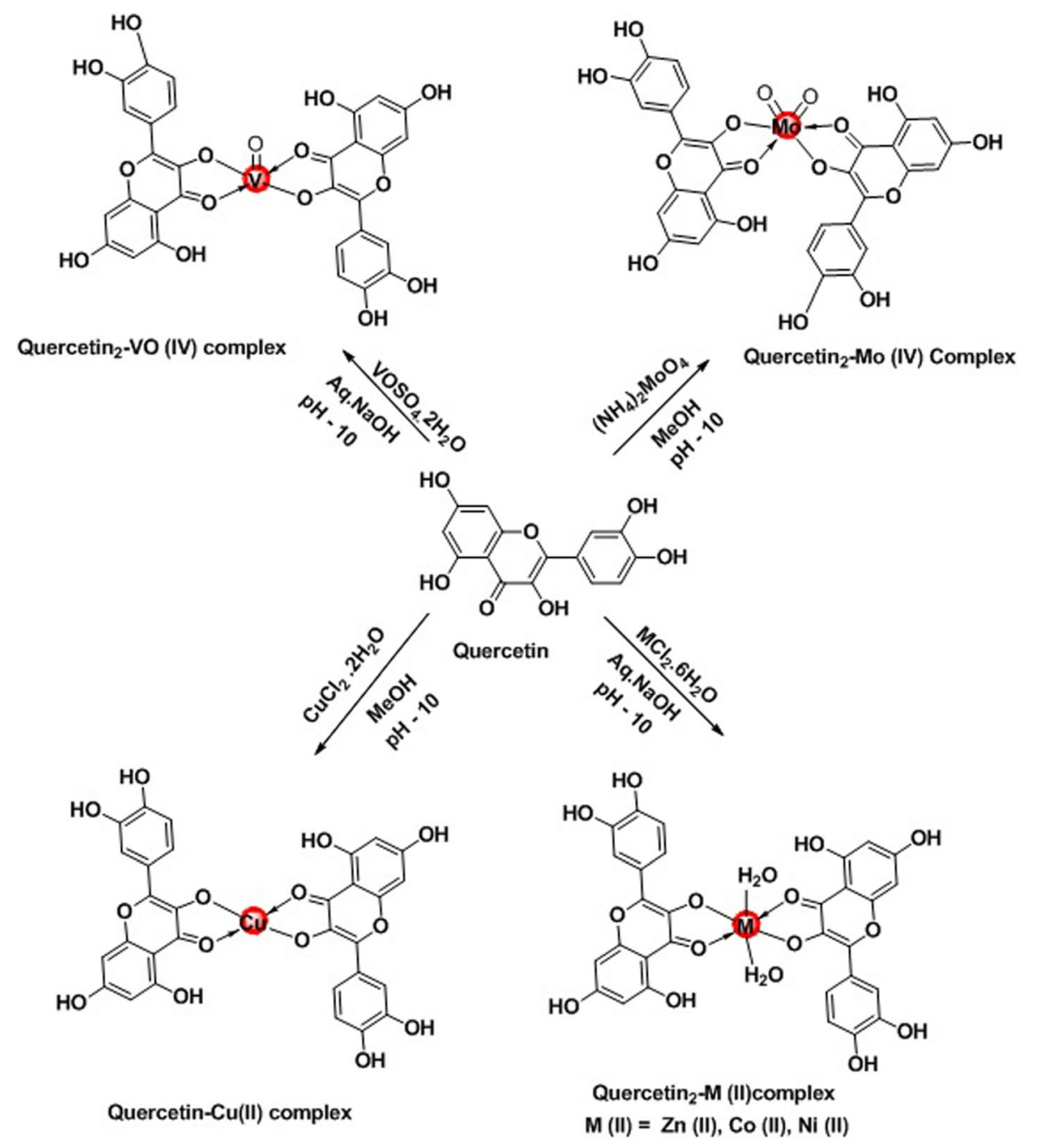

Scheme 1 Synthesis of quercetin-metal (Q-M) complexes 
Table 1 Physical data of quercetin-metal complexes

\begin{tabular}{llll}
\hline S. no. & Metal complexes & Color & \% Yield \\
\hline 1 & Quercetin-copper & Brownish yellow & 83.07 \\
2 & Quercetin-zinc & Dark brown & 82.63 \\
3 & Quercetin-molybdenum & Dark red & 80.80 \\
4 & Quercetin-vanadyl & Brownish yellow & 82.90 \\
5 & Quercetin-nickel & Pale yellow & 80.39 \\
6 & Quercetin-cobalt & Dark brown & 84.64 \\
\hline
\end{tabular}

\section{Animals}

Twenty-four healthy Wistar albino adult male rats 7-9 weeks of age, weighing between 200 and $250 \mathrm{~g}$, procured from Mahaveer Enterprises (reg no. 146/1999 CPCSEA) Hyderabad, Telangana, were used in this research work. The animals were accommodated at the animal house of the institute approved by the Committee for the Purpose of Control and Supervision of Experiments on Animals (CPCSEA) (reg. no. 1047/ac/07 CPCSEA). They were maintained under standard laboratory conditions at an ambient temperature of $25 \pm 2{ }^{\circ} \mathrm{C}$ and $50 \pm 15 \%$ relative humidity, with a 12-h light/dark cycle. Rats were fed with a commercial pellet (Hindustan lever Pvt. Ltd. Mumbai, India) diet and water ad libitum. They were overnight fasted prior to the experiment. The animal experiments were performed in accordance with the CPCSEA guidelines after prior approval of the study protocol by the Institutional Animal Ethics Committee (IAEC).

\section{Spectral analyses of quercetin complexes}

UV-visible study of quercetin and its metal complexes $(\mathrm{Cu}, \mathrm{Zn}, \mathrm{Mo}, \mathrm{VO}, \mathrm{Ni}, \mathrm{Co})$ were carried out in the wavelength range of 200 to $500 \mathrm{~nm}$ by using UV-visible spectrophotometer. Infrared spectral study of these complexes was performed using IR spectrophotometer and the obtained spectral data were analyzed [9, 26, 27].

\section{Preparation of quercetin-metal complexes}

The quercetin-metal complexes have been synthesized and prepared according to previously reported method [28].The $\mathrm{Cu}(\mathrm{II}), \mathrm{Zn}(\mathrm{II}), \mathrm{Ni}(\mathrm{II})$, and $\mathrm{Co}(\mathrm{II})$ complexes were prepared using respective metal chlorides; VO(IV) complex was prepared using vanadyl sulphate; and Mo(IV) complex was prepared using its ammonium salt.

In the preparation of all the metal complexes, the metal and the quercetin compounds were combined in 1:2 mole ratio (the metal being in slight excess of the desired ratio) using appropriate quantities of aqueous methanolic quercetin and methanolic or aqueous metal salt solutions, respectively. The $\mathrm{pH}$ of the solutions was adjusted to 10 by adding sodium hydroxide solution.

\section{General procedure for the preparation of quercetin-metal complexes}

To a hot methanolic solution of quercetin taken in a 50-ml two-necked round-bottomed flask equipped with magnetic stirrer, a solution of an appropriate metal salt (copper chloride dihydrate $\left(\mathrm{CuCl}_{2} \cdot 2 \mathrm{H}_{2} \mathrm{O}\right)$, zinc chloride hexahydrate $\left(\mathrm{ZnCl}_{2} \cdot 6 \mathrm{H}_{2} \mathrm{O}\right)$, nickel chloride hexahydrate $\left(\mathrm{NiCl}_{2} \cdot 6 \mathrm{H}_{2} \mathrm{O}\right)$, cobaltous chloride hexahydrate $\left(\mathrm{CoCl}_{2} \cdot 6 \mathrm{H}_{2} \mathrm{O}\right)$, vanadyl sulphate monohydrate $\left(\mathrm{VOSO}_{4} \cdot \mathrm{H}_{2} \mathrm{O}\right)$, ammonium molybdate $\left.\left(\left(\mathrm{NH}_{4}\right)_{2} \mathrm{MoO}_{4}\right)\right)$ in methanol was added dropwise with stirring and the resultant mixture was heated under reflux for 4-8 h. Obtained solids were filtered off and washed with diethyl ether and dried under vacuum (Scheme 1).

\section{Pharmacological evaluation \\ Everted rat sac method}

The in vitro everted sac technique was introduced by Wilson and Wiseman [29] and later modified into modern everted sac technique. It is a simple, renowned tool to study various pharmacokinetic phenomena like absorption, metabolism, and interaction of drugs and to carry out studies related to multidrug resistance (MDR), role of efflux transporters, and the effect of MDR modulators on drug absorption in the gut. This model involves the gentle eversion of a freshly excised portion of rat small intestine using a glass rod, clamping, and tying one end of the segment and filling it with appropriate solution, sealing the other end tightly, immersing the obtained sac in physiological solution maintained at $37{ }^{\circ} \mathrm{C}$, collecting the samples at different time intervals, and analyzing the results obtained. The everted sac technique measures the serosalto-mucosal transport of drug substrates [30, 31] unlike the non-everted sac technique which measures the mucosal to serosal transport of drug substrates [32].

The animals were overnight fasted and anaesthetized using isoflurane ( $2-3 \%$ by drop jar method). After anaesthetizing the animals, they were euthanized with cervical decapitation and the whole small intestine of each animal was isolated and flushed with $50 \mathrm{ml}$ of ice-cold saline. The small intestine was divided into duodenum, jejunum, and ileum $(n=3)$. Segments were everted, and 10 -cm-long sacs were prepared. About $1 \mathrm{ml}$ of atorvastatin

Table 2 UV-spectral data of quercetin-metal complexes

\begin{tabular}{llllllll}
\hline Bands & $\begin{array}{l}\text { Quercetin (Q) } \\
(\mathbf{n m})\end{array}$ & $\begin{array}{l}\text { Cu(II)-Q complex } \\
(\mathbf{n m})\end{array}$ & $\begin{array}{l}\text { Zn(II)-Q complex } \\
(\mathbf{n m})\end{array}$ & $\begin{array}{l}\text { Mo(II)-Q complex } \\
(\mathbf{n m})\end{array}$ & $\begin{array}{l}\text { VO(IV)-Q complex } \\
(\mathbf{n m})\end{array}$ & $\begin{array}{l}\text { Ni(II)-Q complex } \\
(\mathbf{n m})\end{array}$ & $\begin{array}{l}\text { Co(II)-Q complex } \\
(\mathbf{n m})\end{array}$ \\
\hline $\mathrm{I}$ & 369 & 401 & 403 & 410 & 404 & 415 & 424 \\
$\|$ & 252 & 263 & 253 & 339 & 257 & 257 & 263 \\
\hline
\end{tabular}


Table 3 HPLC profile of atorvastatin

\begin{tabular}{ll}
\hline Concentration $(\mu \mathrm{g} / \mathrm{ml})$ & Peak height $(\mathrm{mAU})$ \\
\hline 0 & 0 \\
0.05 & 61 \\
0.1 & 116 \\
0.25 & 150 \\
0.5 & 285 \\
1 & 500 \\
2.5 & 1268 \\
5 & 2588 \\
\hline
\end{tabular}

solution $(1 \mu \mathrm{g} / \mathrm{ml})$ in DMSO was introduced into the everted sacs (serosal side) and both ends of the sacs were ligated tightly. The sacs $(n=3)$ containing atorvastatin solution were immersed on their mucosal side into $30 \mathrm{ml}$ of Dulbecco's phosphate buffer solution (D-PBS) containing $30 \mu \mathrm{M}$ concentration of glucose and $30 \mu \mathrm{M}$ concentration of quercetin-metal complexes (Q-M; $\mathrm{M}=\mathrm{Cu}, \mathrm{Co}, \mathrm{Ni}, \mathrm{Zn}$, Mo, VO) in DMSO. The buffer solution was prewarmed and oxygenated throughout the experiment. Similarly, the sacs $(n=3)$ filled with atorvastatin without any inhibitor on mucosal side served as control and the sacs $(n=3)$ filled with the atorvastatin and verapamil $(300 \mu \mathrm{M})$ on mucosal side served as standard [33, 34].

The Everted sac model, i.e., intestinal serosal-to-mucosal transport of atorvastatin was measured by the periodic collection of samples from the mucosal medium at different time intervals $(0,10,30,45,60 \mathrm{~min})$. All the samples were mixed with acetonitrile in 2:1 ratio, vortexed ( $2 \mathrm{~min}$ ), and centrifuged at $3000 \mathrm{rpm}$ (15 min). Aliquots of supernatant were separated, filtered through membrane filter $(0.22-\mu \mathrm{m}$ pore size) and preserved at $-20{ }^{\circ} \mathrm{C}$ until analysis. Twenty microliters of it was injected into the HPLC column using a Hamilton syringe. The transport of atorvastatin in the absence of P-gp inhibitor (control), in the presence of Q-M complexes (test) or verapamil (standard) was measured by validated reverse-phase high-performance liquid chromatography (RP-HPLC) method [35]. Apparent permeability coefficients $\left(P_{\text {app }}\right)$ of atorvastatin were calculated from the equation [36] given:

$$
P_{\text {app }}=\frac{\mathrm{dQ}}{\mathrm{dt}} \cdot \frac{1}{A C_{0}}
$$

where $\mathrm{dQ} / \mathrm{dt}$ is the steady-state appearance rate on the acceptor solution

$A$ is the surface area of the intestinal sacs $\left(7.85 \mathrm{~cm}^{2} /\right.$ $\mathrm{sac})$

$C_{0}$ is the initial concentration of drug (inside the sac)

\section{Sensitive RP-HPLC method \\ Chromatographic conditions}

Acetonitrile and water in the proportion of 60:40 (v/v) adjusted to $\mathrm{pH} 2.8$ with phosphate buffer was used as mobile phase, stationary phase was a $\mathrm{C}$-18 reverse-phase column of $250 \times 4.6 \mathrm{~mm}$ dimension, and $5 \mu$ particle size, flow rate was $1 \mathrm{ml} / \mathrm{min}$ at $\lambda$ max of $247 \mathrm{~nm}$, run time was < $15 \mathrm{~min}$, injection volume was $20 \mu \mathrm{l}$, and AUFS (absorbance units full scale) was 0.005 .

\section{Preparation of calibration curve of atorvastatin Preparation of stock solutions}

A stock solution representing $1 \mathrm{mg} / \mathrm{ml}$ of atorvastatin was prepared in methanol. The working standard solutions were prepared prior to use from stock solution by sequential dilution with methanol to yield final concentrations of $0.05,0.1,0.25,0.5,1,2.5$, and $5 \mu \mathrm{g} / \mathrm{ml}$ of atorvastatin.

\section{Construction of calibration curve}

The calibration curve was constructed using peak height ratios of the drug versus concentration [37]. The slope of the plot determined by the method of linear regression analysis was used to calculate the atorvastatin

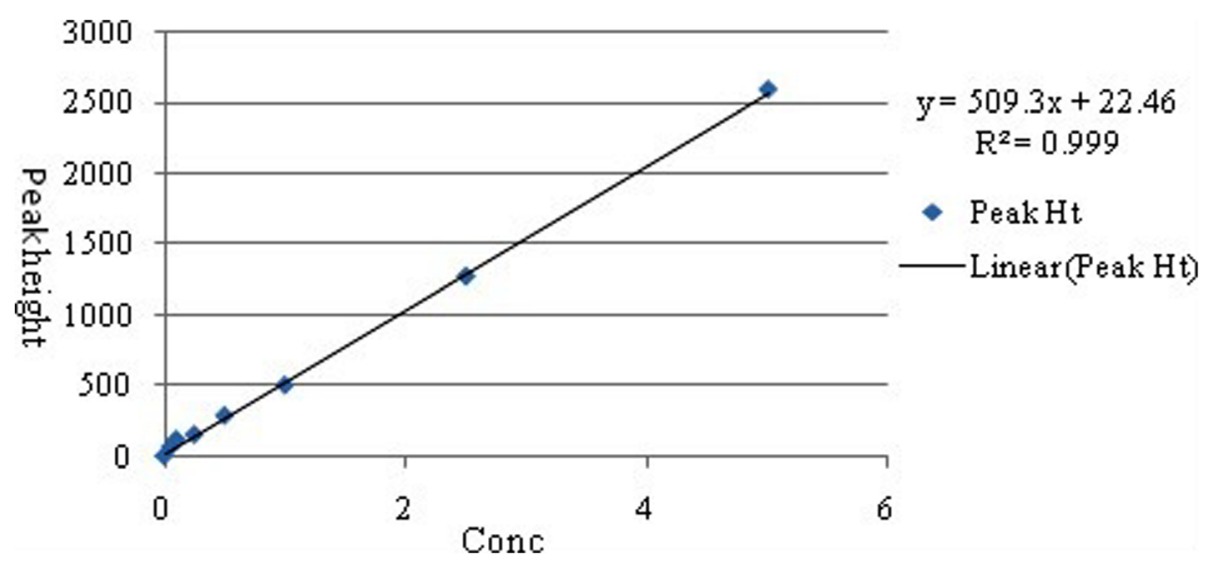

Fig. 1 Calibration curve of atorvastatin 


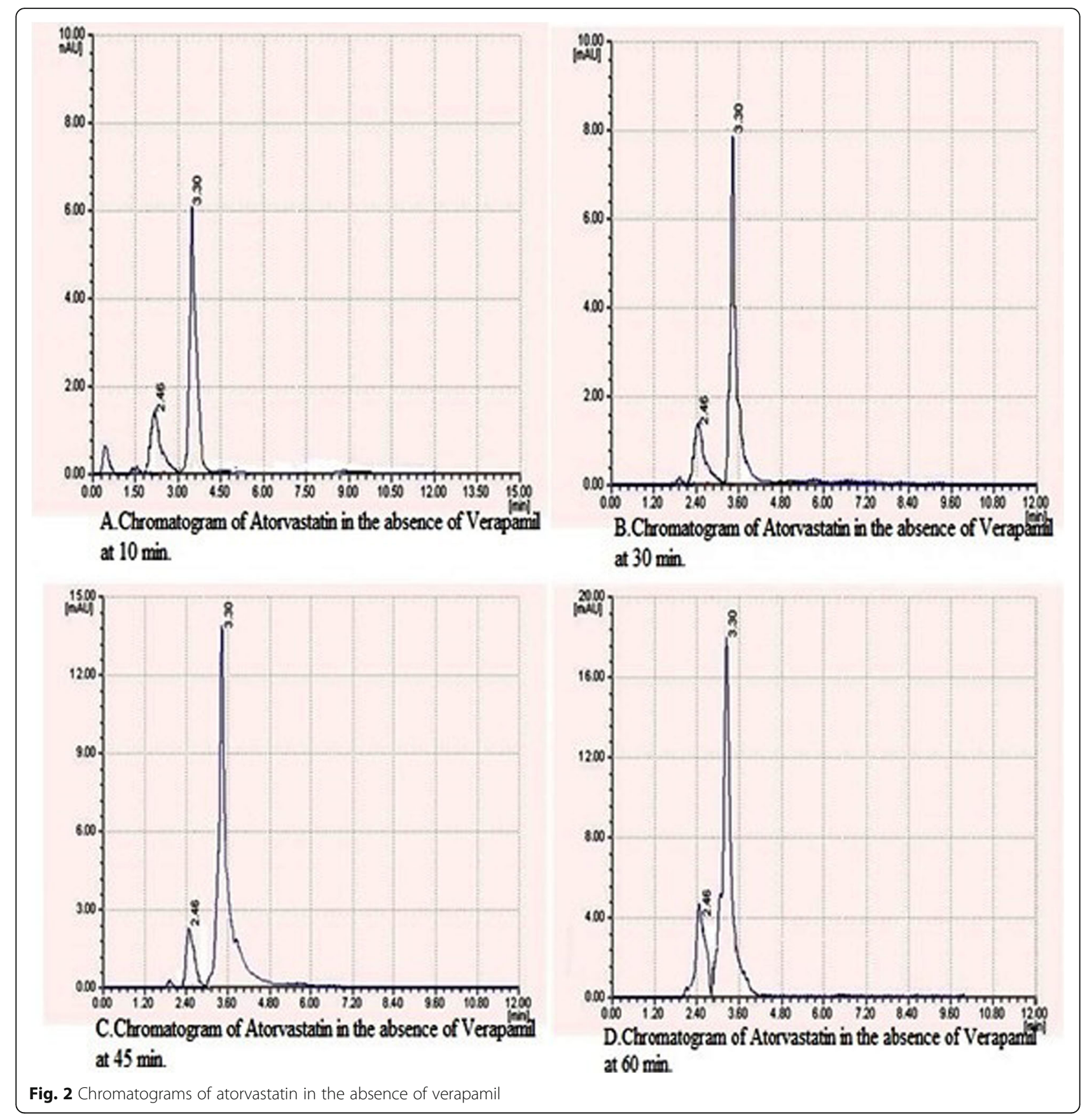

concentration in the unknown sample. A linear regression curve in the range of 0.05 to $5 \mu \mathrm{g} / \mathrm{ml}$ was established.

\section{Statistical analysis}

The in vitro results were compared by Student's paired $t$-test using Graph Pad Instant Software version-5.0. A value of $p<0.05$ was considered statistically significant.

\section{Results}

Chemistry

Addition of aqueous sodium hydroxide during the synthesis of metal complexes resulted in the deprotonation of the $\mathrm{OH}$ groups and thus favored the stability of quercetin at $\mathrm{pH}$ 10. All the metallic salts were soluble in the reaction mixture except cobaltous chloride hexahydrate which was dissolved using dimethyl formamide. All the quercetin-metal complexes were obtained in good yields ranging from 80.39 to $84.64 \%$ as indicated in Table 1 . 


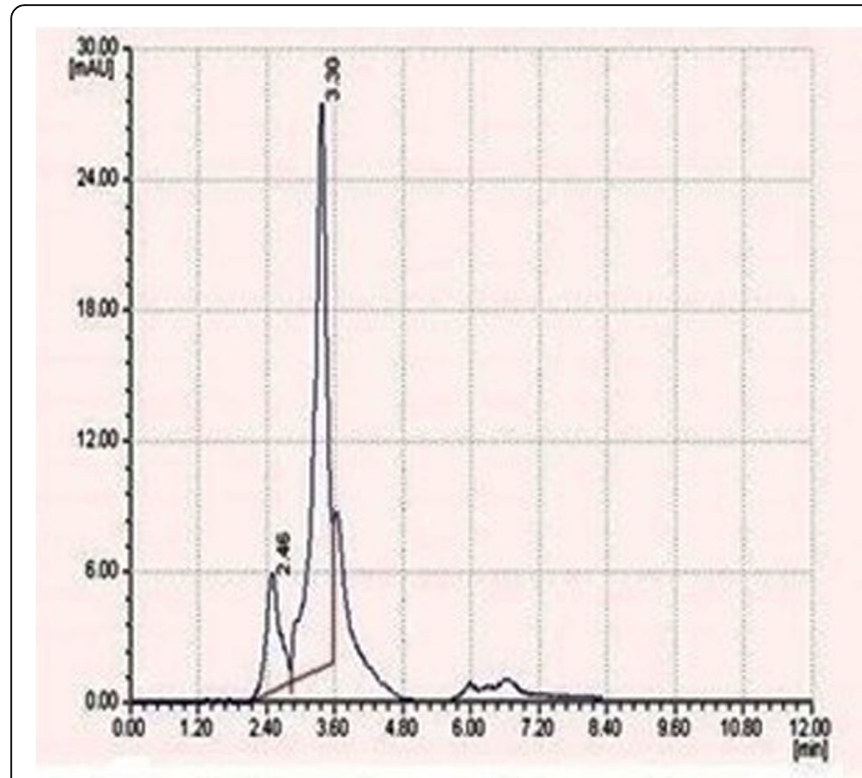

A. Chromatogram of Atorvastatin in presence of verapamil at $10 \mathrm{~min}$.

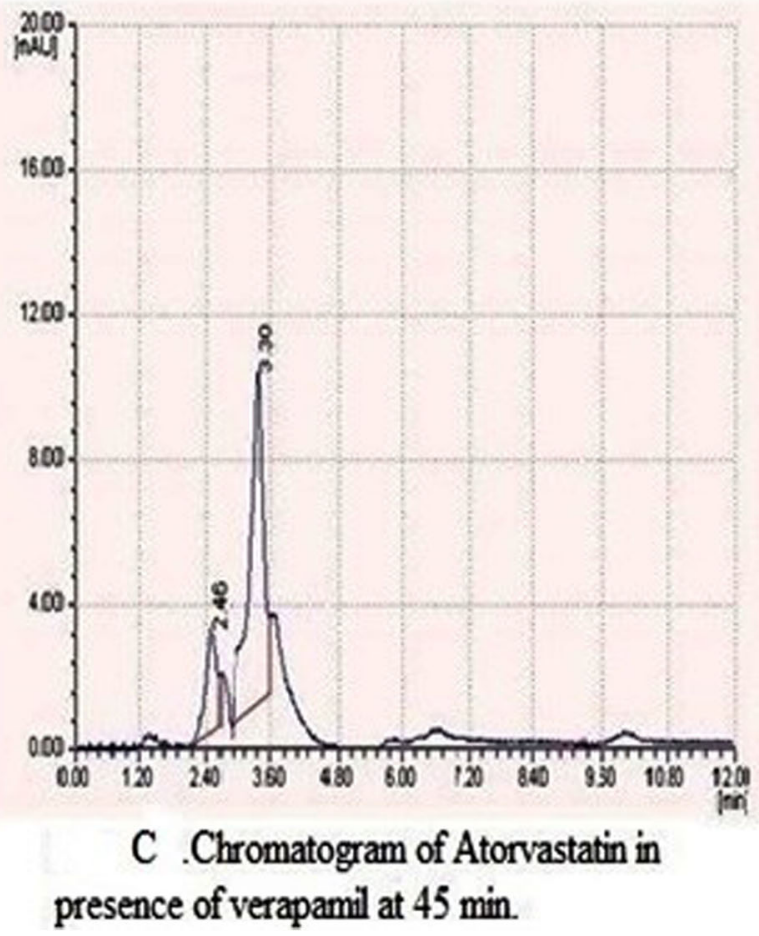

Fig. 3 Chromatograms of atorvastatin in presence of verapamil (300 $\mu \mathrm{M})$

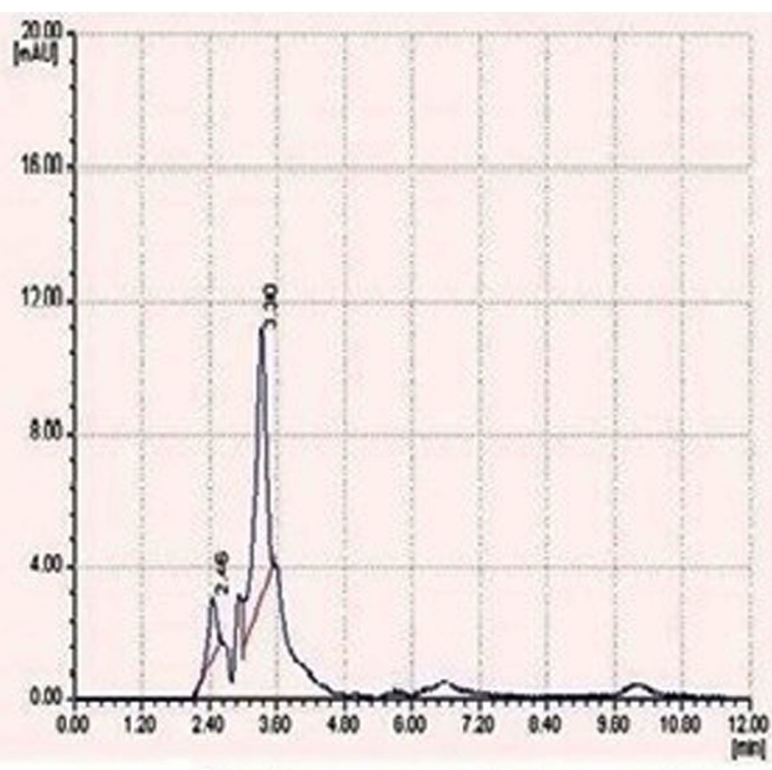

\section{B. Chromatogram of Atorvastatin in presence of verapamil at $30 \mathrm{~min}$.}

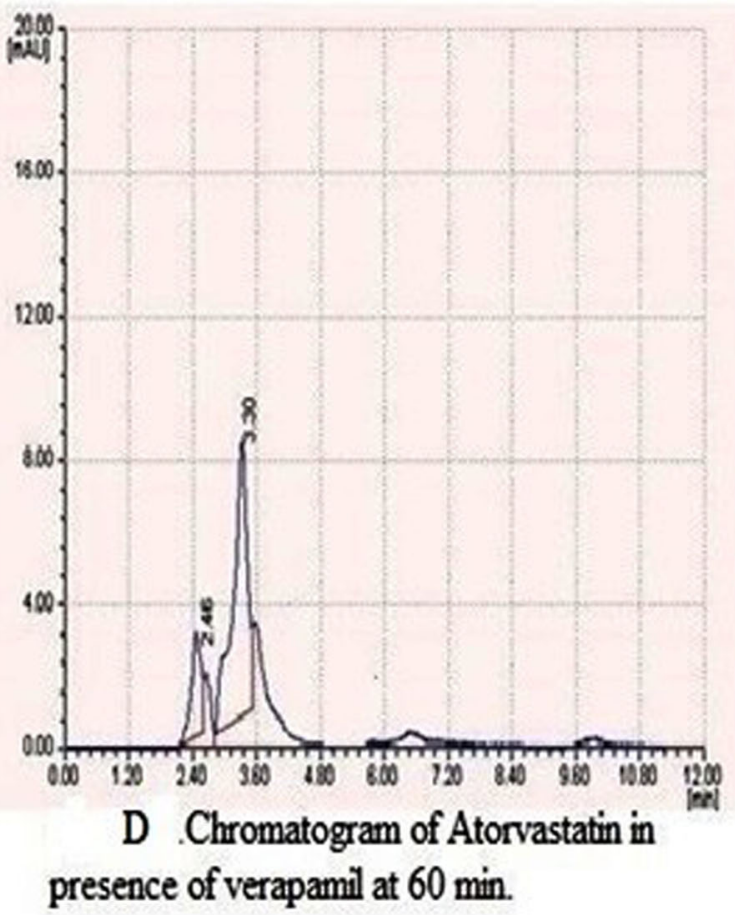

UV-visible study of the quercetin-metal complexes

The UV-visible spectrum of quercetin in DMSO and phosphate buffer shows two major absorption bands due to $\pi-\pi^{*}$ transitions at 369 (band-I) and $252 \mathrm{~nm}$ (band-II) (Table 2). When the solution of a metallic salt was added, bands I and II gradually shifted to longer wavelengths, accompanied with slight decrease in absorption. The results indicated formation of a complex between quercetin and respective metal ions. Band-I bathochromic shift (401 nm) is a common feature observed with all the quercetin-metal complexes. It could be due to the interaction of metal ions $(\mathrm{Cu}, \mathrm{Zn}, \mathrm{Co}, \mathrm{VO}, \mathrm{Mo}$, and $\mathrm{Ni}$ ) with the 3-hydroxy and 4- 


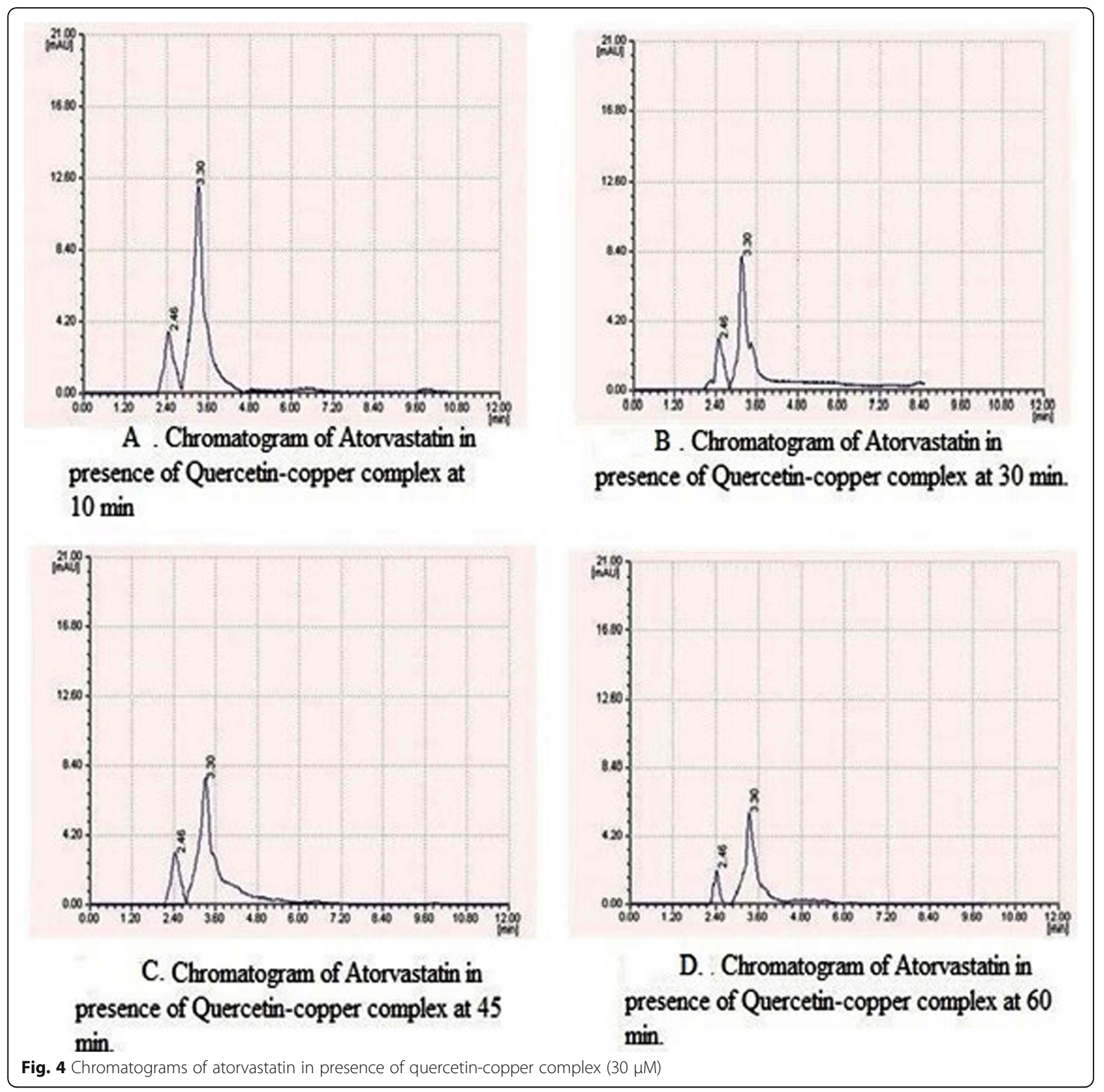

carbonyl groups, the two possible chelating sites on quercetin resulting in electronic redistribution between the quercetin molecule and metal ion.

Infrared spectral study of the quercetin-metal complexes Quercetin showed peaks at $3417 \mathrm{~cm}^{-1}$ (broad) for $\mathrm{O}-\mathrm{H}$ stretch, $1665 \mathrm{~cm}^{-1}$ for $\mathrm{C}=\mathrm{O}$ stretch, $1510 \mathrm{~cm}^{-1}$ for $\mathrm{C}=\mathrm{C}$ stretch, $1316 \mathrm{~cm}^{-1}$ for $\mathrm{OH}$ bend, $1243 \mathrm{~cm}^{-1}$ for $\mathrm{C}-\mathrm{O}$ stretch, and $1162 \mathrm{~cm}^{-1}$ and $997 \mathrm{~cm}^{-1}$ for $\mathrm{CH}$ bend. The presence of peaks at 3355, 3370, 3398, 3325, 3379 , and $3395 \mathrm{~cm}^{-1}$ in IR spectra of the quercetinmetal complexes indicate the formation of $\mathrm{O}-\mathrm{Cu}, \mathrm{O}-$ $\mathrm{Zn}$, O-Mo, O-VO, O-Ni, and O-Co bonds, respectively, through the complexes $[27,38]$. The $\mathrm{C}=$ $\mathrm{O}$ stretching mode of the free ligand (quercetin) occurs at $1665 \mathrm{~cm}^{-1}$. By the interaction of ligand with copper acetate/zinc chloride/ammonium molybdate/ vanadyl sulphate monohydrate/ammonium nickel sulphate hexahydrate/cobaltous chloride hexahydrate, it has been shifted to $1655,1658,1633,1637,1627$, and $1637 \mathrm{~cm}^{-1}$, respectively, which can be explained by coordination of carbonyl oxygen with $\mathrm{Cu}^{2+}, \mathrm{Zn}^{2+}$, $\mathrm{Mo}^{2-}, \mathrm{vo}^{2+}, \mathrm{Ni}^{2+}$, and $\mathrm{Co}^{2+}$ ions, respectively. Moreover, an increase in bond order from $1316 \mathrm{~cm}^{-1}$ in ligand to $1346,1342,1325,1342,1352$, and 1371 $\mathrm{cm}^{-1}$, respectively, after complexation with copper, 


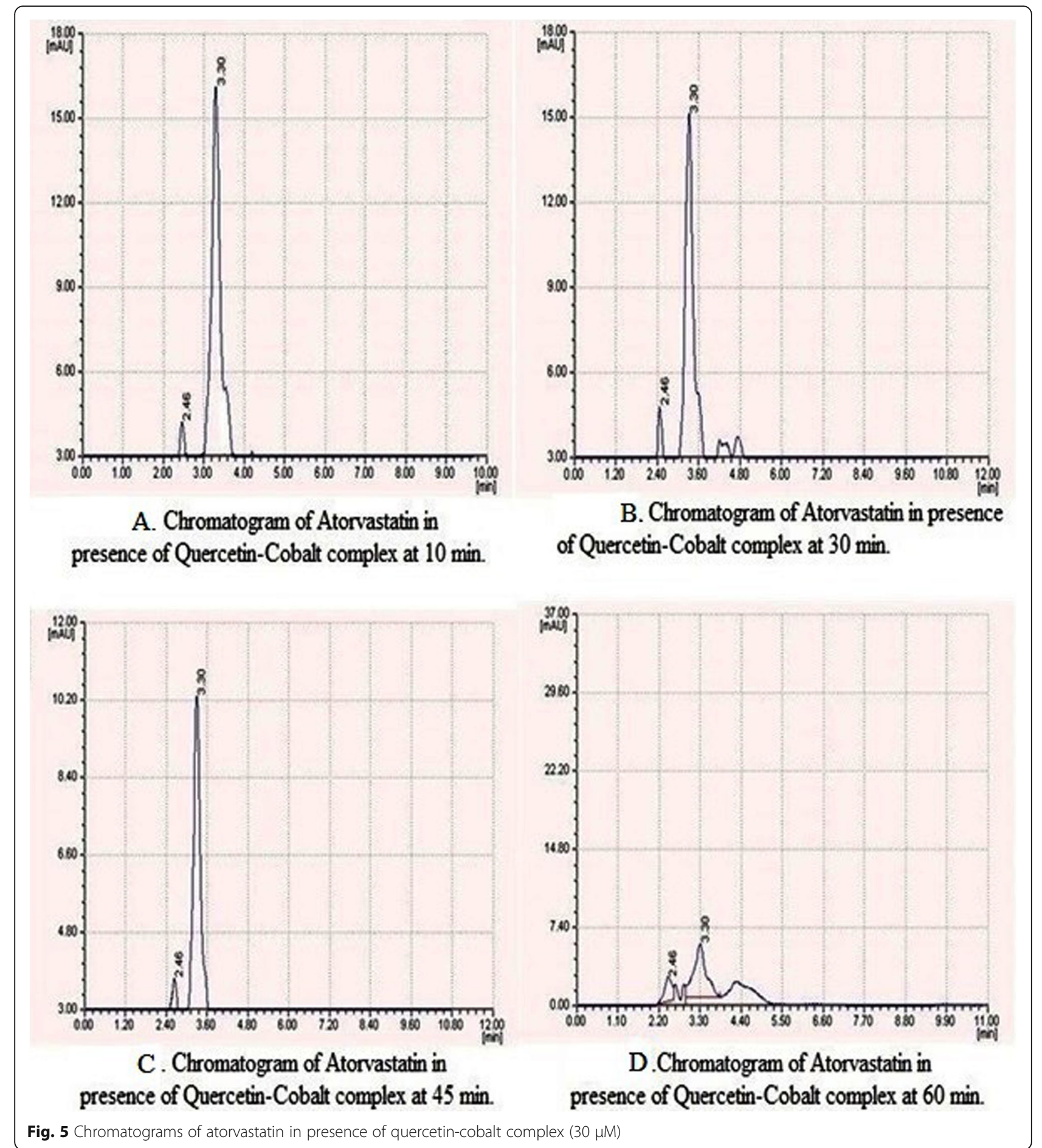

zinc, molybdenum, vanadium, nickel, and cobalt ions, respectively, indicates the involvement of $\mathrm{O}-\mathrm{H}$ deformation vibration which co-ordinates in metal chelation.

\section{Everted rat sac method}

In the present study, the amount of atorvastatin transported from everted sacs (serosal-to-mucosal surface) was determined in different regions of the rat intestine. Control was compared with the standard Pgp inhibitor (verapamil) and quercetin-metal (Q-M) complexes $(\mathrm{M}=\mathrm{Cu}, \mathrm{Zn}, \mathrm{Mo}, \mathrm{VO}, \mathrm{Ni}, \mathrm{Co})$. The transport of atorvastatin across the everted intestinal sacs was determined and expressed as mean \pm SD (standard deviation). 


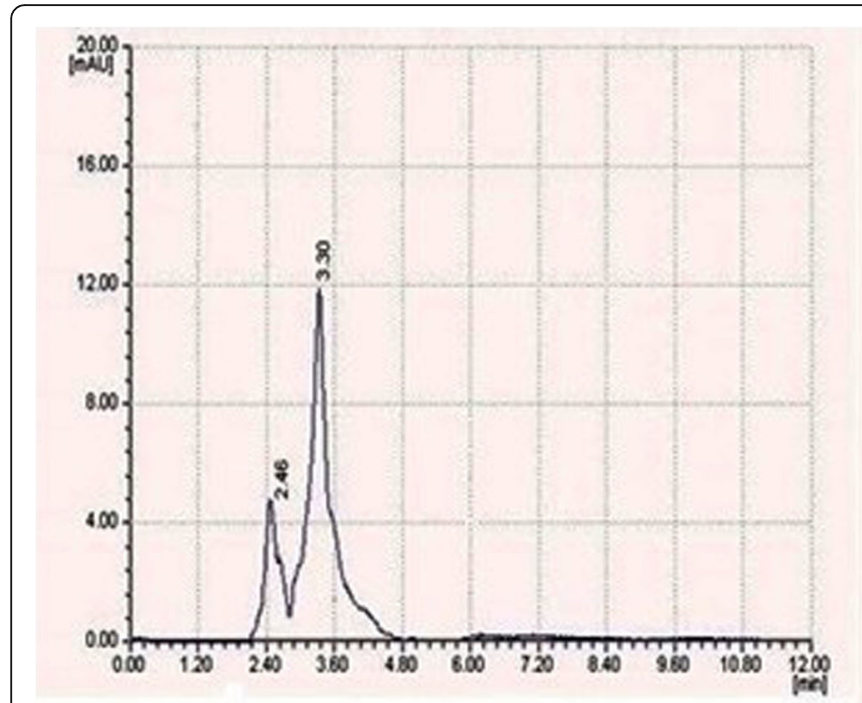

A. Chromatogram of Atorvastatin in presence of Quercetin-Nickel complex at $10 \mathrm{~min}$.

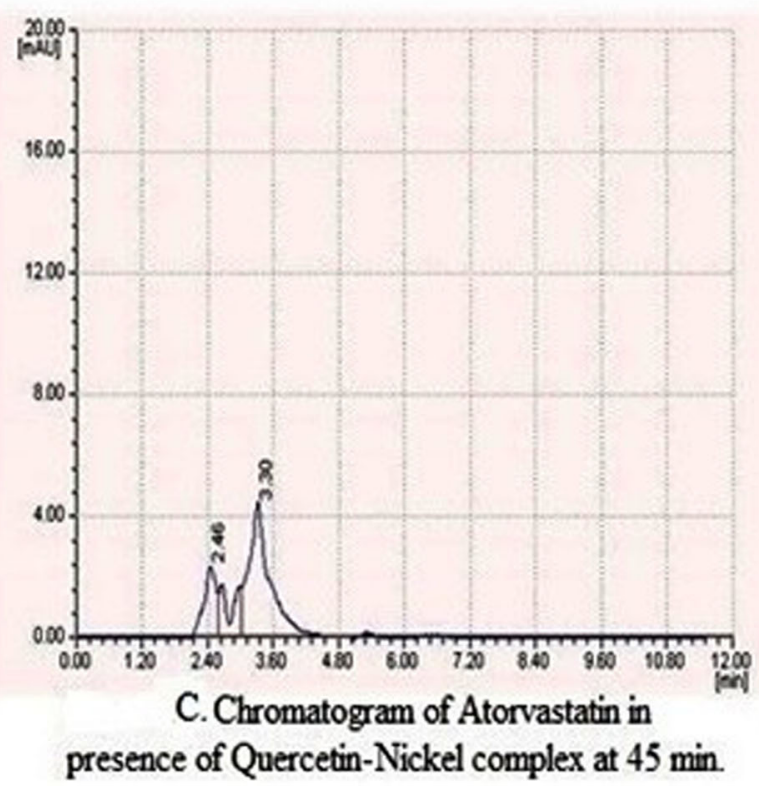

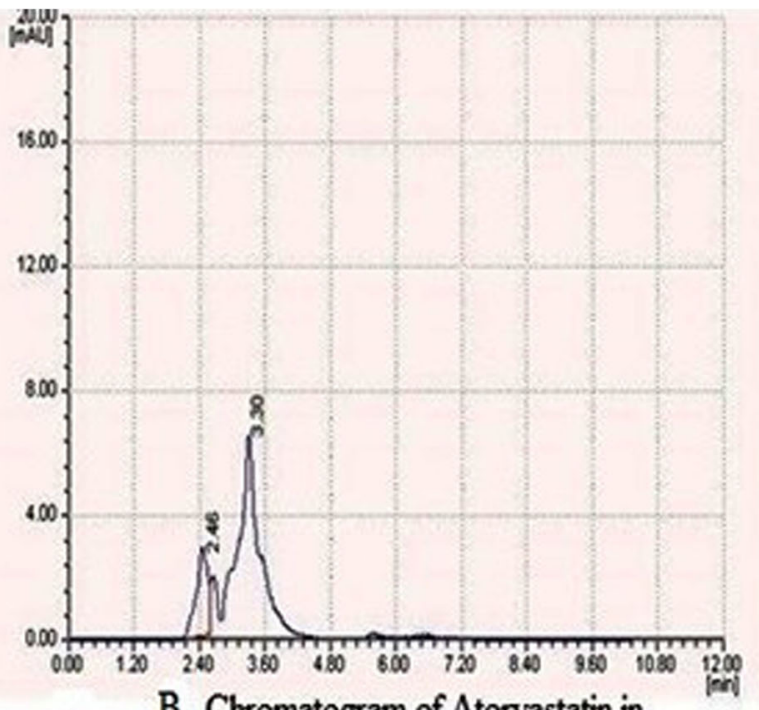

B. Chromatogram of Atorvastatin in presence of Quercetin-Nickel complex at $30 \mathrm{~min}$.

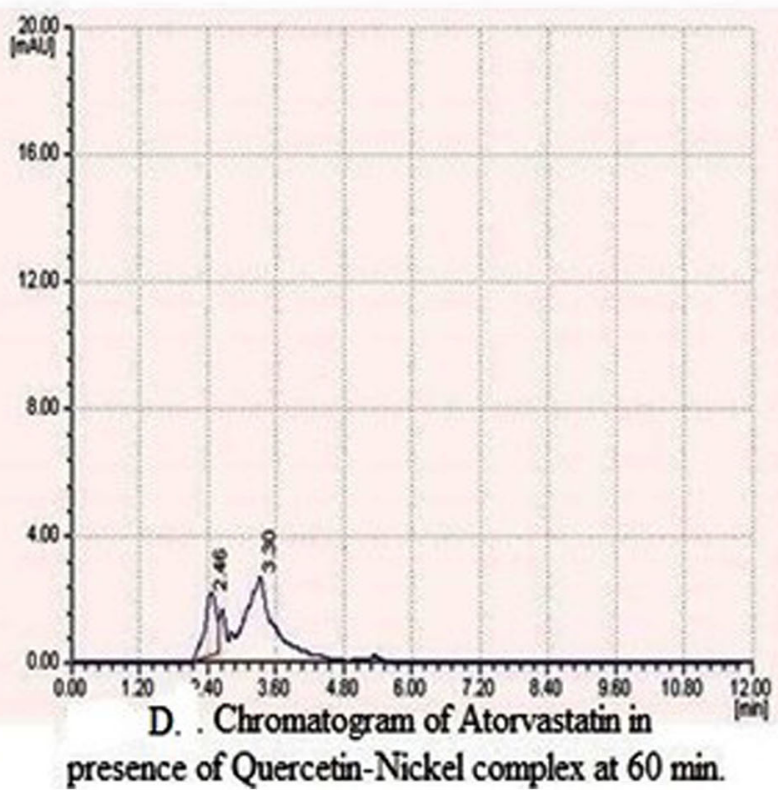

Fig. 6 Chromatograms of atorvastatin in presence of quercetin-nickel complex (30 $\mu \mathrm{M})$

Table 4 Apparent permeability coefficients $\left(P_{\mathrm{app}}\right)\left(\times 10^{-6} \mathrm{~cm} / \mathrm{s}\right)$ of atorvastatin in the everted duodenum of healthy rat small intestine $(n=3)$

\begin{tabular}{|c|c|c|c|c|c|}
\hline \multirow{2}{*}{$\begin{array}{l}\text { Time } \\
(\min )\end{array}$} & \multicolumn{5}{|l|}{ Duodenum } \\
\hline & $\begin{array}{l}\text { Atorvastatin- } \\
\text { treated rats }\end{array}$ & $\begin{array}{l}\text { Atorvastatin }+ \\
\text { verapamil-treated rats }\end{array}$ & $\begin{array}{l}\text { Atorvastatin + Q-Cu } \\
\text { complex-treated rats }\end{array}$ & $\begin{array}{l}\text { Atorvastatin + Q-Co } \\
\text { complex-treated rats }\end{array}$ & $\begin{array}{l}\text { Atorvastatin + Q-Ni } \\
\text { complex-treated rats }\end{array}$ \\
\hline 10 & $0.030 \pm 0.003$ & $0.028 \pm 0.001$ & $0.035 \pm 0.001$ & $0.035 \pm 0.001$ & $0.042 \pm 0.001$ \\
\hline 30 & $0.036 \pm 0.003$ & $0.026 \pm 0.002$ & $0.024 \pm 0.001$ & $0.019 \pm 0.001$ & $0.027 \pm 0.000$ \\
\hline 45 & $0.073 \pm 0.019$ & $0.022 \pm 0.002^{*}$ & $0.023 \pm 0.001^{*}$ & $0.012 \pm 0.001^{* *}$ & $0.020 \pm 0.001^{*}$ \\
\hline 60 & $0.119 \pm 0.060$ & $0.010 \pm 0.002^{* * *}$ & $0.021 \pm 0.001^{* * *}$ & $0.010 \pm 0.0004^{* * *}$ & $0.009 \pm 0.0001^{* * *}$ \\
\hline
\end{tabular}

All values expressed as mean $\pm S D .{ }^{*} p<0.05$ significant, ${ }^{* *} p<0.01$ highly significant, ${ }^{* * *} p<0.001$ very highly significant, compared to atorvastatin control 
Table 5 Apparent permeability coefficients $\left(P_{\mathrm{app}}\right)\left(\times 10^{-6} \mathrm{~cm} / \mathrm{s}\right)$ of atorvastatin in the everted jejunum of healthy rat small intestine $(n=3)$

\begin{tabular}{|c|c|c|c|c|c|}
\hline \multirow{2}{*}{$\begin{array}{l}\text { Time } \\
(\min )\end{array}$} & \multicolumn{5}{|l|}{ Jejunum } \\
\hline & $\begin{array}{l}\text { Atorvastatin- } \\
\text { treated rats }\end{array}$ & $\begin{array}{l}\text { Atorvastatin }+ \\
\text { verapamil-treated rats }\end{array}$ & $\begin{array}{l}\text { Atorvastatin + Q-Cu } \\
\text { complex-treated rats }\end{array}$ & $\begin{array}{l}\text { Atorvastatin + Q-Co } \\
\text { complex-treated rats }\end{array}$ & $\begin{array}{l}\text { Atorvastatin }+\mathrm{Q}-\mathrm{Ni} \\
\text { complex-treated rats }\end{array}$ \\
\hline 10 & $0.034 \pm 0.004$ & $0.032 \pm 0.002$ & $0.027 \pm 0.001$ & $0.028 \pm 0.001$ & $0.031 \pm 0.001$ \\
\hline 30 & $0.042 \pm 0.004$ & $0.028 \pm 0.002$ & $0.022 \pm 0.002$ & $0.017 \pm 0.002$ & $0.022 \pm 0.001$ \\
\hline 45 & $0.078 \pm 0.019$ & $0.026 \pm 0.003$ & $0.020 \pm 0.002^{*}$ & $0.012 \pm 0.001^{*}$ & $0.016 \pm 0.001^{*}$ \\
\hline 60 & $0.131 \pm 0.074$ & $0.023 \pm 0.004^{* *}$ & $0.019 \pm 0.002^{* *}$ & $0.009 \pm 0.0005^{* *}$ & $0.007 \pm 0.0002^{* *}$ \\
\hline
\end{tabular}

All values expressed as mean \pm SD. ${ }^{*} p<0.05$ significant, ${ }^{* *} p<0.001$ very highly significant, compared to atorvastatin control

\section{RP-HPLC method of analysis}

In the present study, the atorvastatin concentrations were estimated by a sensitive RP-HPLC method (Table 3 ). The calibration curve of atorvastatin was plotted with concentration versus peak height as shown in Fig. 1. The typical chromatograms corresponding to solvent buffer and atorvastatin in the absence and presence of verapamil and in the presence of quercetin-metal complexes at different time points of the experimental study are depicted in Figs. 2, 3, 4, 5, and 6. The separation of both peaks (solvent and atorvastatin) was satisfactory, with retention times of $2.46 \mathrm{~min}$ and $3.30 \mathrm{~min}$, respectively.

Tables 4, 5, and 6 reveal the apparent permeability coefficients $\left(P_{\text {app }}\right)$ of atorvastatin alone (control) and in presence of verapamil (standard) and the quercetinmetal complexes (test) in the everted duodenum, jejunum, and ileum, respectively.

\section{Discussion}

Clinically, multidrug resistance (MDR) is one of the major causes for chemotherapeutic treatment failure in cancer patients. Several strategies for overcoming drug resistance have been studied, including (1) developing reversal agents which target drug resistance markers such as P-gp and MRP1, (2) developing new agents to which drug-resistant cancer cells are sensitive, (3) employing agents to which drug-resistant cancer cells show collateral sensitivity, and (4) developing antiangiogenesis therapy and gene therapy for drug-resistant cancer cells [39]. Among them, developing reversal agents which target P-gp has been a principal strategy.

Multidrug resistance of cancer cells is often associated with over expression of P-gp, a plasma membrane transporter that extrudes chemotherapeutic drugs by using ATP hydrolysis as the energy source. P-gp is encoded by the MDR1 gene and functions as an energy-dependent multidrug membrane transporter that rapidly extrudes a variety of hydrophobic anticancer drugs from target cancer cells and thereby prevents the drugs from exerting cytotoxic effects. Since the first P-gp inhibitor, verapamil, was found in 1981, a variety of agents including cyclosporin A (CysA) and others have been reported as agents for overcoming MDR [40].

However, the clinical trial results of these drugs are very disappointing so far, due to dose-limiting toxicity. Therefore, it is necessary to find new reversing agents with lesser side effects. Natural sources come under this category of having no dose-limiting toxicity and lesser side effects $[41,42]$. Several members of flavonoids were found to be able to modulate drug efflux in MDR cancer cells, such as genistein, quercetin, and naringenin [43, 44]. The flavonoid quercetin was shown to inhibit P-gp-mediated drug transport by inhibiting the ATP binding site of P-gp. It was reported to decrease the expression of P-gp significantly in multidrug-resistant human cervical carcinoma (KBV1) cells at the concentration of $30 \mu \mathrm{M}$ [45].

Experimental studies proved that quercetin exhibits both P-gp inhibitory and antitumor activities and it also

Table 6 Apparent permeability coefficients $\left(P_{\text {app }}\right)\left(\times 10^{-6} \mathrm{~cm} / \mathrm{s}\right)$ of atorvastatin in the everted ileum of healthy rat small intestine $(n$ =3)

\begin{tabular}{|c|c|c|c|c|c|}
\hline \multirow{2}{*}{$\begin{array}{l}\text { Time } \\
(\min )\end{array}$} & \multicolumn{5}{|l|}{ Ileum } \\
\hline & $\begin{array}{l}\text { Atorvastatin- } \\
\text { treated rats }\end{array}$ & $\begin{array}{l}\text { Atorvastatin }+ \\
\text { verapamil-treated rats }\end{array}$ & $\begin{array}{l}\text { Atorvastatin + Q-Cu } \\
\text { complex-treated rats }\end{array}$ & $\begin{array}{l}\text { Atorvastatin + Q-Co } \\
\text { complex-treated rats }\end{array}$ & $\begin{array}{l}\text { Atorvastatin + Q-Ni } \\
\text { complex-treated rats }\end{array}$ \\
\hline 10 & $0.040 \pm 0.003$ & $0.041 \pm 0.002$ & $0.023 \pm 0.001$ & $0.022 \pm 0.002$ & $0.023 \pm 0.0006$ \\
\hline 30 & $0.046 \pm 0.004$ & $0.036 \pm 0.003$ & $0.019 \pm 0.001$ & $0.015 \pm 0.001$ & $0.018 \pm 0.001$ \\
\hline 45 & $0.085 \pm 0.021$ & $0.033 \pm 0.002$ & $0.018 \pm 0.001$ & $0.009 \pm 0.001$ & $0.013 \pm 0.001$ \\
\hline 60 & $0.169 \pm 0.122$ & $0.032 \pm 0.003^{*}$ & $0.016 \pm 0.001^{* *}$ & $0.007 \pm 0.0001^{* *}$ & $0.005 \pm 0.0002^{* *}$ \\
\hline
\end{tabular}

All values expressed as mean \pm SD. ${ }^{*} p<0.01$ highly significant, ${ }^{* *} p<0.001$ very highly significant, compared to atorvastatin control 
has the ability to chelate metal ions [16]. Further, some metal complexes show P-gp inhibitory activity [46-48]. But till now, there are no reports on P-gp inhibitory activity of quercetin-metal complexes.

In the present study, we have synthesized metal $(\mathrm{Cu}, \mathrm{Co}, \mathrm{Ni}, \mathrm{Zn}, \mathrm{Mo}, \mathrm{VO})$ complexes of quercetin in high yields and purity and characterized them by using UV-visible and IR spectral data. From spectroscopic studies, quercetin was found to chelate metal ions $(\mathrm{Cu}, \mathrm{Co}, \mathrm{Ni}, \mathrm{Zn}, \mathrm{Mo}, \mathrm{VO})$ at the 3-hydroxy and 4-carbonyl groups. They were pharmacologically evaluated for their P-gp inhibitory activity by in vitro everted sac method in rats by comparing the apparent permeability of P-gp substrate (atorvastatin) with that of standard P-gp inhibitor, verapamil.

Results of this in vitro study revealed that the transport of atorvastatin (P-gp substrate) across the small intestine is much affected by the $\mathrm{Q}-\mathrm{Cu}, \mathrm{Q}-\mathrm{Co}$, and $\mathrm{Q}-\mathrm{Ni}$ complex treatment. The mean $\pm \mathrm{SD}$ and apparent permeability of atorvastatin decreased in the presence of the $\mathrm{Q}-\mathrm{Cu}, \mathrm{Q}-\mathrm{Co}$, and $\mathrm{Q}-\mathrm{Ni}$ complexes. A time-dependent effect was observed. Also, a significant reduction in the Papp values was observed in the everted sacs treated with Q-Cu, Q-Co, and Q-Ni complexes as compared with controls. All the three metal complexes were found to be more potent than the standard verapamil at all three sites of small intestine (i.e., duodenum, jejunum, and ileum) at only one-tenth dose of verapamil. Among the three complexes, Q-Ni complex exhibited superior inhibitory activity on the permeability glycoprotein (P-gp). Next to it, Q-Co complex significantly reduced the transport of atorvastatin across the intestinal membranes. The rest of the complexes (QMo, Q-Zn, Q-VO) did not show any effect on the transport of atorvastatin and hence considered inactive. The study revealed that Q-Cu, Q-Co, and Q$\mathrm{Ni}$ metal complexes could inhibit P-gp (at much lesser concentrations than verapamil) and increase the absorption of atorvastatin.

\section{Conclusion}

The transport of atorvastatin (P-gp substrate) across the small intestine is much affected by the Q-Cu, Q-Co, and $\mathrm{Q}-\mathrm{Ni}$ complexes treatment. The treatment of sacs with these metal complexes decreased the intestinal permeation of atorvastatin (P-gp substrate) when compared with that of standard P-gp inhibitor and control, which may be due to inhibition of P-glycoprotein. Hence, they could be considered P-gp inhibitors and studied further.

\section{Abbreviations}

RP-HPLC: Reverse-phase high-performance liquid chromatography; MDR: Multidrug resistance; M: Metal; Q: Quercetin; Q-Cu: Quercetin-copper complex; Q-Zn: Quercetin-zinc complex; Q-Mo: Quercetin-molybdenum complex; Q-Vo: Quercetin-vanadyl complex; Q-Ni: Quercetin-nickel complex; Q-Co: Quercetin-cobalt complex; P-gp: P-glycoprotein (permeability glycoprotein); SD: Standard deviation; UV: Ultraviolet spectrophotometer; IR: Infrared spectrophotometer; CPCSEA: Committee for the Purpose of Control and Supervision of Experiments on Animals; IAEC: Institutional Animal Ethics Committee

\section{Acknowledgements \\ The authors are thankful to the Management, Principal, and H.O.D (Pharmacology) for providing the necessary facilities.}

\section{Authors' contributions}

SK conceptualized the project and gave technical inputs in conducting the study and preparing manuscript. KS performed the entire study under the guidance of SK. HK assisted KS during the experimental work. KD prepared the manuscript. SBBS and SKB gave technical inputs in conducting the animal studies, analyzing the results, drafting the manuscript, and substantively revised it. RG assisted KS in synthesizing the metal complexes, under the guidance of MK. The authors have read and approved the manuscript.

Funding

None.

Availability of data and materials

All data and materials are available upon request.

\section{Declarations}

Ethics approval and consent to participate

The animal experiments were performed after prior approval of the study protocol by the Institutional Animal Ethics Committee (application no. 44/ IAECNCOP/2013).

Consent for publication

Not applicable.

\section{Competing interests}

The authors declare that they have no competing interests.

\section{Author details}

'Departments of Pharmaceutical Chemistry and Pharmacology, Vaagdevi College of Pharmacy, Ramnagar, Hanamkonda, Warangal, Telangana 506001, India. ${ }^{2}$ Department of Chemistry, Kakatiya University, Vidyaranyapuri, Warangal, Telangana 506009, India. ${ }^{3}$ Clinical Development Division, Sanofi India, South Goa, Goa 403722, India.

Received: 13 January 2021 Accepted: 26 April 2021

Published online: 08 May 2021

\section{References}

1. Siegel RL, Miller KD, Jemal A (2020) Cancer statistics. CA A Cancer J Clin 70(1):7-30. https://doi.org/10.3322/caac.21590

2. Smith RD, Mallath MK (2019) History of the growing burden of cancer in India: from antiquity to the 21st century. J Glob Oncol 5:1-15. https://doi. org/10.1200/JGO.19.00048

3. Zheng HC (2017) The molecular mechanisms of chemoresistance in cancers, Oncotarget 8(35):59950-59964. https://doi.org/10.18632/oncotarget.19048

4. Schirrmacher V (2019) From chemotherapy to biological therapy: a review of novel concepts to reduce the side effects of systemic cancer treatment (Review). Int J Oncol 54(2):407-419. https://doi.org/10.3892/ijo.2018.4661

5. Wang X, Zhang H, Chen X (2019) Drug resistance and combating drug resistance in cancer. Cancer Drug Resist 2:141-160

6. Salehi B, Machin L, Monzote L, Sharifi-Rad J, Ezzat SM, Salem MA, Merghany RM, El Mahdy NM, Kılıç CS, Sytar O, Sharifi-Rad M, Sharopov F, Martins N, Martorell M, Cho WC (2020) Therapeutic potential of quercetin: new insights and perspectives for human health. ACS Omega 5(20):11849-11872. https:// doi.org/10.1021/acsomega.0c01818

7. Lesjak M, Beara I, Simin N, Pintać D, Majkić T, Bekvalac K, Orčić D, Mimica-Dukić N (2018) Antioxidant and anti-inflammatory activities of quercetin and its derivatives. J Funct Foods 40:68-75. https://doi.org/10.1016/j.jf.2017.10.047 
8. Xu D, Hu M-J, Wang Y-Q, Cui Y-L (2019) Antioxidant activities of quercetin and its complexes for medicinal application. Molecules 24(6):1123-1138. https://doi.org/10.3390/molecules24061123

9. Torreggiani A, Tamba M, Trinchero A, Bonora S (2005) Copper (II)-quercetin complexes in aqueous solutions: spectroscopic and kinetic properties. J Mol Struct 744-747:759-766

10. De Castilho TS, Matias TB, Nicolini KP, Nicolini J (2018) Study of interaction between metal ions and quercetin. Food Sci Human Wellness 7(3):215-219. https://doi.org/10.1016/j.fshw.2018.08.001

11. Liu Y, Guo M (2015) Studies on transition metal-quercetin complexes using electrospray ionization tandem mass spectrometry. Molecules 20(5):85838594. https://doi.org/10.3390/molecules20058583

12. Ahmadi SM, Dehghan G, Hosseinpourfeizi MA, Dolatabadi JE, Kashanian S (2011) Preparation, characterization, and DNA binding studies of watersoluble quercetin--molybdenum(VI) complex. DNA Cell Biol 30(7):517-523. https://doi.org/10.1089/dna.2010.1205

13. Khater M, Ravishankar D, Greco F, Osborn HMI (2019) Metal complexes of flavonoids: their synthesis, characterization and enhanced antioxidant and anticancer activities. Future Med Chem 11(21):2845-2867. https://doi.org/1 0.4155/fmc-2019-0237

14. Da Silva WMB, de Oliveira PS, Alves DR, de Morais MS (2020) Synthesis of quercetin-metal complexes, in vitro and in silico anticholinesterase and antioxidant evaluation, and in vivo toxicological and anxiolitic activities. Neurotox Res 37(4):893-903. https://doi.org/10.1007/s12640-019-00142-7

15. Ulusoy HG, Sanlier N (2020) A minireview of quercetin: from its metabolism to possible mechanisms of its biological activities. Crit Rev Food Sci Nutr 60(19):3290-3303. https://doi.org/10.1080/10408398.2019.1683810

16. Massi A, Bortolini O, Ragno D, Bernardi T, Sacchetti G, Tacchini M, De Risi C (2017) Research progress in the modification of quercetin leading to anticancer agents. Molecules 22(8):1270. https://doi.org/10.3390/ molecules 22081270

17. Chen X, Wu X, He Z, Zhang J, Cao Y, Mao D, Feng C, Tian B, Chen G (2020) Molecular docking-assisted design and synthesis of an anti-tumor quercetin-Se(IV) complex. New J Chem 44(20):8434-8441. https://doi.org/1 0.1039/C9NJ06136C

18. Roy S, Banerjee S, Chakraborty T (2018) Vanadium quercetin complex attenuates mammary cancer by regulating the P53, Akt/mTOR pathway and downregulates cellular proliferation correlated with increased apoptotic events. Biometals 31(4):647-671. https://doi.org/10.1007/s10534-018-0117-3

19. Li S, Zhao Q, Wang B, Yuan S, Wang X, Li K (2018) Quercetin reversed MDR in breast cancer cells through down-regulating P-gp expression and eliminating cancer stem cells mediated by YB-1 nuclear translocation. Phytother Res 32(8):1530-1536. https://doi.org/10.1002/ptr.6081

20. Zhou Y, Zhang J, Wang K, Han W, Wang X, Gao M, Wang Z, Sun Y, Yan H, Zhang H, Xu X, Yang D-H (2020) Quercetin overcomes colon cancer cells resistance to chemotherapy by inhibiting solute carrier family 1 , member 5 transporter. Eur J Pharmacol 881:173185. https://doi.org/10.1016/j.ejphar.202 0.173185

21. Shin SC, Choi JS, Li X (2006) Enhanced bioavailability of tamoxifen after oral administration of tamoxifen with quercetin in rats. Int J Pharm 313(1-2):144149. https://doi.org/10.1016/j.jpharm.2006.01.028

22. Mohana S, Ganesan M, Agilan B, Karthikeyan R, Srithar G, Mary RB, Ananthakrishnan D, Velumurugan D, Rajendraprasad N, Ambudkar SV (2016) Screening dietary flavonoids for the reversal of P-glycoprotein mediated multidrug resistance in cancer. Mol BioSyst 12(8):2458-2470. https://doi. org/10.1039/C6MB00187D

23. Kim MK, Choo H, Chong Y (2014) Water-soluble and cleavable quercetinamino acid conjugates as safe modulators of P-glycoprotein based multidrug resistance. J Med Chem 57(17):7216-7233. https://doi.org/10.1 021/jm500290C

24. Nolan JP, Hare MDDK, McDevitt MDJJ, Ali MVMD (1977) In vitro studies of intestinal endotoxin absorption I. Kinetics of absorption in the isolated everted gut sac. Gastroenterology 72(3):434-439

25. Alam MA, Al-Jenoobi Fl, Al-mohizea AM (2011) Everted gut sac model as a tool in pharmaceutical research: limitations and applications. J Pharm Pharmacol 64:326-336

26. Mondal P, Bose A (2019) Spectroscopic overview of quercetin and its Cu (II) complex interaction with serum albumins. Bioimpacts 9(2):115-121. https:// doi.org/10.15171/bi.2019.15

27. Kalinowska M, Świderski G, Matejczyk M, Lewandowski W (2016) Spectroscopic, thermogravimetric and biological studies of $\mathrm{Na}(\mathrm{I}), \mathrm{Ni}(\mathrm{II})$ and
Zn(II) complexes of quercetin. J Therm Anal Calorim 126(1):141-148. https:// doi.org/10.1007/s10973-016-5362-5

28. Dehghan G, Khoshkam Z (2012) Tin (II)-quercetin complex: synthesis, spectral characterization and antioxidant activity. Food Chem 131(2):422426. https://doi.org/10.1016/j.foodchem.2011.08.074

29. Wilson $\mathrm{TH}$, Wiseman $\mathrm{G}$ (1954) The use of sacs of everted small intestine for the study of the transference of substances from the mucosal to the serosal surface. J Physiol 123:116-125.

30. Challa VR, Ravindra Babu P, Challa SR, Johnson B, Maheswari C (2013) Pharmacokinetic interaction study between quercetin and valsartan in rats and in vitro models. Drug Dev Ind Pharm 39(6):865-872. https://doi.org/1 0.3109/03639045.2012.693502

31. Adukondalu D, Shravan Kumar Y, Vamshi Vishnu Y, Shiva Kumar R, Madhusudan Rao Y (2010) Effect of pomegranate juice pre-treatment on the transport of carbamazepine across rat intestine. DARU J Pharm Sci 18:254-259

32. Bedada SK, Appani R, Boga PK (2017) Capsaicin pretreatment enhanced the bioavailability of fexofenadine in rats by P-glycoprotein modulation: in vitro, in situ and in vivo evaluation. Drug Dev Ind Pharm 43(6):932-938. https:// doi.org/10.1080/03639045.2017.1285310

33. Yumoto R, Murakami T, Nakamoto Y, Hasegawa R, Nagai J, Takano M (1999) Transport of rhodamine 123, a P-glycoprotein substrate, across rat intestine and Caco-2 cell monolayers in the presence of cytochrome P-450 3Arelated compounds. J Pharmacol Exper Ther 289:149-155

34. Li M, Si L, Pan H, Rabba AK, Yan F, Qiu J, Li G (2011) Excipients enhance intestinal absorption of ganciclovir by P-gp inhibition: assessed in vitro by everted gut sac and in situ by improved intestinal perfusion. Int J Pharm 403(1-2):37-45. https://doi.org/10.1016/j.jpharm.2010.10.017

35. Sultana N, Arayne MS, Naveed S (2010) Simultaneous determination of captopril and statins in API, pharmaceutical formulations and in human serum by RP-HPLC. J Chin Chem Soc 57(3A):378-383. https://doi.org/10.1 002/jccs.201000056

36. Ruan LP, Chen S, Yu BY, Zhu DN, Cordell GA, Qiu SX (2006) Prediction of human absorption of natural compounds by the non-everted rat intestinal sac model. Eur J Med Chem 41(5):605-610. https://doi.org/10.1016/j. ejmech.2006.01.013

37. Hu L, Song W, Zhang H, Gu D (2013) HPLC-UV method development for atorvastatin calcium micro-emulsion determination in rat plasma and its application to elucidate pharmacokinetic behavior after oral administration to rats. Int J Pharm Sci Res 4:3839-3844

38. Nakamoto K (2008) Infrared and Raman spectra of inorganic and coordination compounds: part A: theory and applications in inorganic chemistry, 6th edn. Wiley, Hoboken. pp 149-354. https://www.scirp.org/\%2 85\%28vtj3fa45qm1ean45vvffcz55\%29\%29/reference/referencespapers.a spx?referenceid $=2193348$

39. Saraswathy M, Gong S (2013) Different strategies to overcome multidrug resistance in cancer. Biotechnol Adv 31(8):1397-1407. https://doi.org/10.101 6/.j.biotechadv.2013.06.004

40. Sirisha K, Achaiah G, Prasad N, Bhasker S, Umachander L, Malla Reddy V (2018) Multidrug resistance reversal activity of some new dihydropyridines studied by in situ single-pass intestinal perfusion (SPIP) method in rat. Pharm Chem J 52(1):8-14. https://doi.org/10.1007/s1 1094-018-1757-x

41. Dewanjee S, Dua TK, Bhattacharjee N, Das A, Gangopadhyay M, Khanra R, Joardar S, Riaz M, Feo V, Zia-Ul-Haq M (2017) Natural products as alternative choices for P-glycoprotein (P-gp) inhibition. Molecules 22(6):871. https://doi. org/10.3390/molecules22060871

42. Seukep AJ, Kuete V, Nahar L, Sarker SD, Guo M (2020) Plant-derived secondary metabolites as the main source of efflux pump inhibitors and methods for identification. J Pharmaceut Anal 10(4):277-290. https://doi. org/10.1016/j.jpha.2019.11.002

43. Abdallah HM, Al-Abd AM, El-Dine RS, El-Halawany AM (2015) P-glycoprotein inhibitors of natural origin as potential tumor chemo-sensitizers: a review. J Adv Res 6(1):45-62. https://doi.org/10.1016/j.jare.2014.11.008

44. Wu CP, Ohnuma S, Ambudkar SV (2011) Discovering natural product modulators to overcome multidrug resistance in cancer chemotherapy. Curr Pharm Biotechnol 12(4):609-620. https://doi.org/10.2174/138920111795163887

45. Borska S, Sopel M, Chmielewska M, Zabel M, Dziegiel P (2010) Quercetin as a potential modulator of P-glycoprotein expression and function in cells of human pancreatic carcinoma line resistant to daunorubicin. Molecules 15(2): 857-870. https://doi.org/10.3390/molecules15020857

46. Zaman R, Ali G, Anjum Z, Sajid M, Khan MM, Ahmad A, Abbas SR, Rehman W (2018) Discovery of a tin-piperonal-entecavir Schiff base compound that 
overcomes multidrug resistance by inhibiting P-glycoprotein. Assay Drug Dev Technol 16(4):205-211. https://doi.org/10.1089/adt.2018.844

47. Côrte-Real L, Karas B, Gírio P, Moreno A, Avecilla F, Marques F, Buckley BT, Cooper KR, Doherty C, Falson P, Garcia MH, Valente A (2019)

Unprecedented inhibition of P-gp activity by a novel rutheniumcyclopentadienyl compound bearing a bipyridine-biotin ligand. Eur J Med Chem 163:853-863. https://doi.org/10.1016/j.ejmech.2018.12.022

48. Spengler G, Kincses A, Rácz B, Varga B, Watanabe G, Saijo R, Sekiya H, Tamai E, Maki J, Molnár J, Kawase M (2018) Benzoxazole-based Zn(II) and Cu(II) complexes overcome multidrug-resistance in cancer. Anticancer Res 38(11): 6181-6187. https://doi.org/10.21873/anticanres.12971

\section{Publisher's Note}

Springer Nature remains neutral with regard to jurisdictional claims in published maps and institutional affiliations.

\section{Submit your manuscript to a SpringerOpen ${ }^{\odot}$ journal and benefit from:}

- Convenient online submission

Rigorous peer review

- Open access: articles freely available online

High visibility within the field

- Retaining the copyright to your article

Submit your next manuscript at $\boldsymbol{\nabla}$ springeropen.com 